\title{
Type analysis of the South American diatom Achnanthes haynaldii (Bacillariophyta) and description of Planothidium amphibium sp. nov., from aerial and aquatic environments in Oregon (USA)
}

\author{
Carlos E. Wetzel ${ }^{1, *}$, Bart Van de Vijver ${ }^{2,3}$, Kateřina Kopalová 4 , \\ Lucien Hoffmann ${ }^{1}$, Laurent Pfister $^{1}$ \& Luc Ector ${ }^{1}$
}

${ }^{1}$ Public Research Centre - Gabriel Lippmann, Department of Environment and Agro-biotechnologies (EVA), 41 rue du Brill, LU-4422 Belvaux, Grand-Duchy of Luxembourg

${ }^{2}$ Botanic Garden Meise, Department of Cryptogamy (Bryophyta \& Thallophyta), Nieuwelaan 38, BE-1860 Meise, Belgium ${ }^{3}$ University of Antwerp, Department of Biology, ECOBE, Universiteitsplein 1, BE-2610 Wilrijk, Antwerpen, Belgium ${ }^{4}$ Charles University in Prague, Faculty of Science, Department of Ecology, Viničná 7, CZ-12844 Prague 2, Czech Republic

*Author for correspondence: wetzel@lippmann.lu

\begin{abstract}
Background and aims - Planothidium haynaldii (Schaarschm.) Lange-Bert. ( $=$ Achnanthes haynaldii Schaarschm.) is a widely reported species from temperate and cold zones of southern and northern hemispheres despite being originally described from a high altitude stratovolcano (Antisana, $4100 \mathrm{~m}$ a.s.l.) in Ecuador (tropical climatic zone). Although widely cited in the literature, studies concerning the original material were never carried out. The main objective of this paper is to clarify the identity of Planothidium haynaldii and two related species from North-western USA and Antarctic environments.

Methods - The original type slide of Achnanthes haynaldii Schaarschm. was observed. Additionally, selected samples containing populations currently identified either as Planothidium haynaldii or Achnanthes lanceolata var. capitata O.Müll. collected in Oregon (USA) and James Ross Island (Antarctica) were observed. The samples were analyzed using light (LM) and scanning electron microscopy (SEM).

Key results - A new species, commonly improperly identified as Planothidium haynaldii, is described as Planothidium amphibium C.E.Wetzel, Ector \& L.Pfister sp. nov. from aerial and aquatic habitats of Oregon (USA). This species is widely distributed in the northern hemisphere according to illustrated literature records. Achnanthes lanceolata var. capitata is erected to species level and transferred to the genus Planothidium. Planothidium capitatum (O.Müll.) Van de Vijver, Kopalová, C.E.Wetzel \& Ector comb. $\&$ stat. nov. seems to be an important component of the communities in the Antarctic region where large populations were found on James Ross Island and Livingston Island living in the epilithon and epipelon of large lakes. Finally, Planothidium haynaldii seems to be rarer than initially expected and its occurrence is confirmed only in the Andes mountain range in South America (recent freshwater sample from Ecuador and as fossil in Chile).
\end{abstract}

Key words - Achnanthes, Planothidium, Planothidium haynaldii, type material, biogeography, ecology, SEM.

\section{INTRODUCTION}

Achnanthes haynaldii Schaarschm. was described in 1881 by Julius Schaarschmidt from riverine aquatic plants collected on the stratovolcano Antisana (northern Andes, Ecuador) by Luigi Sodiro. Schaarschmidt (1881) described three varieties, namely: 'vulgaris', ' $\beta$-elliptico-lanceolata' and ' $\gamma$-oblongo-elliptica' without any illustration of the mentioned taxa. The first illustrations were provided by Cleve (1894: 99, plate 2, fig. 14a,b) who observed the original type slide of Schaarschmidt and who considered the species as a variety of Achnanthes lanceolata (Bréb. ex Kütz.) Grunow in Cleve \& Grunow.

Few years later Müller (1909) described a new variety Achnanthes lanceolata var. capitata O.Müll. from the temperate zone of South America (southern Patagonia), slightly different from the variety 'haynaldii' by its smaller dimensions (width and length) and lower striation density. Later, Frenguelli (1930) described a similar species, namely 
Achnanthes looseri Freng., from samples collected in the Andes mountain range close to Antofagasta, Chile. The latter species remained forgotten for a long period until recently analysed and transferred to the genus Planothidium by Rivera \& Cruces (2009).

In Europe and worldwide as well, the most influent publications about diatoms were those of Friedrich Hustedt in the late-mid $20^{\text {th }}$ century. Hustedt (1933) considered Achnanthes haynaldii var. vulgaris Schaarschm. and A. lanceolata var. haynaldii Cleve as synonyms of Achnanthes lanceolata f. capitata (O.Müll.) Hust., while Achnanthes haynaldii var. oblongo-elliptica was considered by him as a synonym of Achnanthes lanceolata [ $\equiv$ Planothidium lanceolatum (Bréb. ex Kütz.) Lange-Bert.] and as a consequence, the epithet 'haynaldii' remained unused for a long period despite the report of seven varieties of Achnanthes haynaldii proposed by Cleve-Euler in 1953 (fig. 528).

North American diatomists followed the species concept of Patrick \& Reimer (1966, p. 271) concerning Achnanthes lanceolata var. haynaldii and considered O. Müller's variety 'capitata' as a synonym of the mentioned taxon. The original drawings provided by the latter authors are shown in the figure 1.

The first light micrographs (LM) of a taxon bearing the epithet 'haynaldii' was a population from the USA ('Sippe aus den USA') provided by Lange-Bertalot \& Krammer (1989: 88, plate 84, figs 20-25) as '(?) Achnanthes lanceolata var. haynaldii'. Lange-Bertalot explicitly used a question mark to his identification and indeed the illustrated valves seem to correspond to the drawings provided by Patrick \& Reimer (1966). Later on, Krammer \& Lange-Bertalot (1991, plate 41, figs 16-20) treated the same population (including the same images) as a subspecies variety: 'Achnanthes lanceolata ssp. lanceolata var. (?) haynaldii'. Bukhtiyarova (1999) assigned this taxon to the genus Planothidium and kept it as a variety [Planothidium lanceolatum var. haynaldii (Schaarchm.) Bukht.], while in the same year Lange-Bertalot
(1999) transferred it also to Planothidium and proposed the new combination Planothidium haynaldii (Schaarschm.) Lange-Bert. All these transfers concerning supra and infraspecific combinations were made without a critical analysis of the type material.

An attempt on solving the identity of species around the 'lanceolata-haynaldii' complex was led by Lowe \& Cody (2002) who discussed several Planothidium species from the USA and concluded that discrepancies concerning valve width between the description of the type material of Achnanthes haynaldii and the populations identified as Planothidium haynaldii from the USA were too high and that additional investigations of the original material should be carried out. Indeed Potapova (2011) pointed out that the original description of Achnanthes haynaldii did not include illustrations and that the type material had never been investigated. Meanwhile the concept followed by North American taxonomists (i.e. Spaulding et al. 2010, Potapova 2011) is the one presented in Patrick \& Reimer (1966).

In this paper we clarify and specify the identity of Achnanthes haynaldii, illustrating for the first time the type material using light microscopy. Moreover, we describe a new similar species from the USA currently misidentified as Planothidium haynaldii and we illustrate a population of Achnanthes lanceolata var. capitata O.Müll. from the Antarctic region, usually regarded as a synonym of Planothidium haynaldii.

\section{MATERIAL AND METHODS}

The material used for description and illustration of Achnanthes haynaldii comes from the original slide (fig. 1A) MIC 3417 "Ecuador 59 Antisana ad 4100 meters (Sodiro)" borrowed from the Naturhistoriska Riksmuseet, Stockholm, Sweden. Since no raw material was available for scanning electron microscope analysis, only LM images are presented.
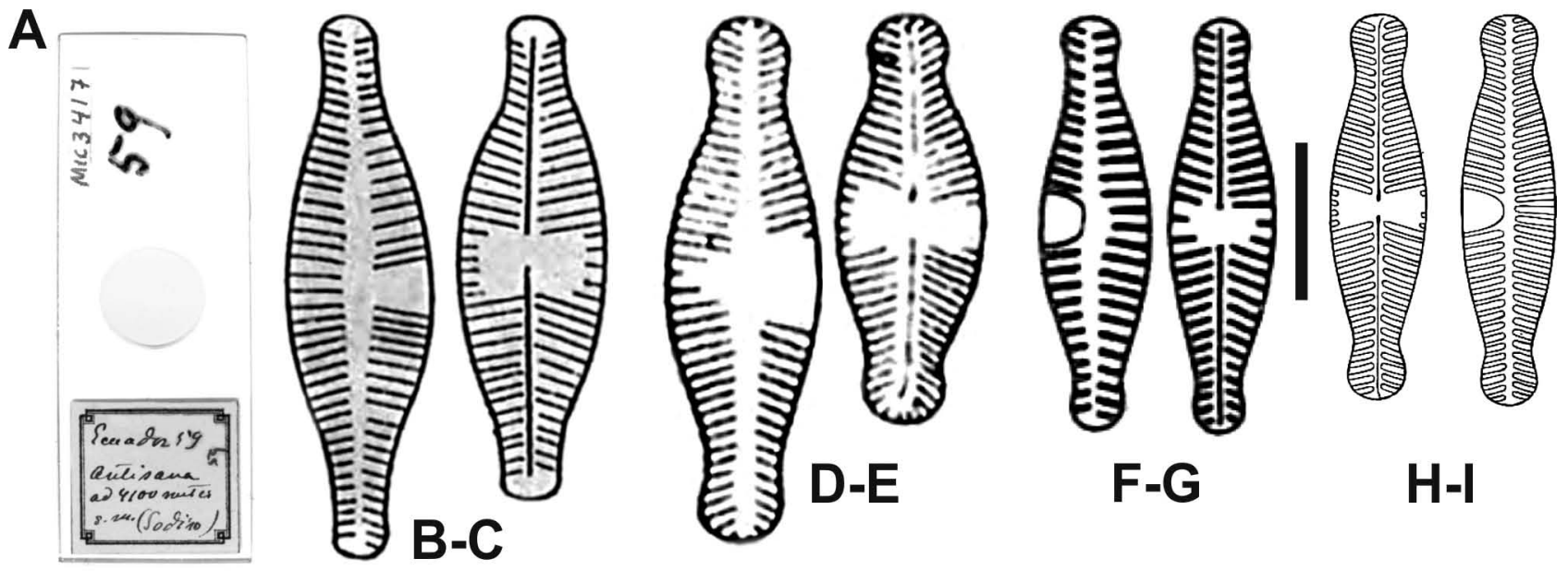

Figure 1 - A, original slide used by Schaarschmidt (1881) to describe Achnanthes haynaldii from Ecuador (Antisana volcano, $4100 \mathrm{~m}$ a.s.l., collected by Sodiro); B-C, drawing of 'Achnanthes lanceolata var. haynaldii' by Cleve (1894, plate 7, fig. 14a,b); D-E, 'Achnanthes (Microneis) looseri' by Frenguelli (1930: 198, fig. 1); F-G, 'Achnanthes lanceolata forma capitata O. Müller' by Hustedt (1933: 410, fig. 863g,h); H-I, 'Achnanthes lanceolata var. haynaldii (Istv.-Schaarsch.) Cl.' published by Patrick \& Reimer (1966: 271, plate 18, figs 20-21). Scale bar represents $10 \mu \mathrm{m}$. 
Wetzel et al., Planothidium amphibium sp. nov. (Bacillariophyta)

Table 1 - Chemical and physical parameters of water samples collected during a runoff event (drift samples) measured in the Oak Creek Watershed, Corvallis, Oregon, USA between 6 and 14 Mar. 2012.

\begin{tabular}{|c|c|c|c|c|c|c|c|c|}
\hline & Unit & $N$ & Min & $\operatorname{Max}$ & Mean & Stand. dev. & Median & $\begin{array}{c}\text { Coeff. var. } \\
(\%)\end{array}$ \\
\hline Conductivity & $\mu \mathrm{S} . \mathrm{cm}^{-1}$ & 47 & 70.00 & 163.70 & 132.73 & 26.84 & 145.60 & 20.22 \\
\hline Sodium & $\mathrm{mg} \cdot \mathrm{L}^{-1}$ & 47 & 2.65 & 7.68 & 5.16 & 1.16 & 5.56 & 22.57 \\
\hline Potassium & $\mathrm{mg} \cdot \mathrm{L}^{-1}$ & 47 & 0.18 & 0.55 & 0.32 & 0.10 & 0.30 & 30.62 \\
\hline Chlorides & $\mathrm{mg} \cdot \mathrm{L}^{-1}$ & 47 & 0.87 & 4.31 & 2.35 & 0.79 & 2.62 & 33.46 \\
\hline Nitrates & mg.L.L & 47 & 0.02 & 1.59 & 0.10 & 0.24 & 0.02 & 230.23 \\
\hline Sulphates & $\mathrm{mg} \cdot \mathrm{L}^{-1}$ & 47 & 0.14 & 3.87 & 1.81 & 0.70 & 1.93 & 38.34 \\
\hline
\end{tabular}

Material used to describe a new similar species was collected at a catchment of $0.208 \mathrm{~km}^{2}$, sub-basin of the $33 \mathrm{~km}^{2}$ Oak Creek Watershed, located near Corvallis, Oregon, U.S.A $\left(44^{\circ} 35^{\prime} 32.3^{\prime \prime} \mathrm{N} 123^{\circ} 19^{\prime} 43.2^{\prime \prime} \mathrm{W}\right)$. The climate in this region is relatively mild and often described as Mediterranean, with dry summers and wet winters. Average temperature in the watershed is $11.5^{\circ} \mathrm{C}$ and mean annual precipitation is approximately $111 \mathrm{~cm} . y e a r^{-1}$ (Oregon Climate Service, www. ocs.oregonstate.edu). The studied catchment is primarily agricultural (sheep and cattle grazing, growth of clover, wheat and fescue) with small inholdings of residential areas (Poor \& McDonnell 2007).

Different types of samples $(n=38)$ were considered for diatom analysis and can be divided in two groups: one group $(\mathrm{n}=8)$ composed of samples from different substrates outside the streambed (aerial environments), such as herbaceous vegetation, litter, bryophytes and soil samples from grasslands plots; a second group $(\mathrm{n}=30)$ comprising water samples collected during a rainstorm event using an automatic water sampler (ISCO 6712 FS) installed a couple of meters upstream a weir to collect stream water samples at frequent intervals during storm runoff events $(0.5-3 \mathrm{~h})$. Sampler contained 24 bottles (1-L) and was linked to the recording stream gauge. Sampling was triggered by flow conditions. A total of 47 samples were collected for water analysis and a total of 30 drift samples for diatom analysis. Abiotic conditions were measured following standard procedures and are listed in table 1.

The samples concerning Achnanthes lanceolata var. capitata were collected from lakes during several field trips on Livingston Island (South Shetland Islands) in the southern Atlantic Ocean and James Ross Island in the northern Weddell Sea. Both localities belong to the Maritime Antarctic Region (Chown \& Convey 2007). Details on sampling methods and physico-chemical analyses can be found in Kopalová \& Van de Vijver (2013) and Kopalová et al. (2013).

Diatom samples for LM observation were prepared following the method described in van der Werff (1955). Subsamples of the original material were oxidized using $37 \%$ $\mathrm{H}_{2} \mathrm{O}_{2}$ and heating to $80^{\circ} \mathrm{C}$ for approximately $1 \mathrm{~h}$. The reaction was further completed by the addition of $\mathrm{KMnO}_{4}$. Following digestion and centrifugation (three times 10 minutes at
3700 r.p.m.), the material free of organic matter was diluted with distilled water for sample mounting to avoid excessive concentrations of diatom valves and frustules on the slides. A subsample from the organic-free material was mounted in Naphrax ${ }^{\circledR}$ for diatom community studies. The slides were analysed using an Olympus ${ }^{\circledR}$ BX53 microscope, equipped with Differential Interference Contrast (Nomarski) and an Olympus ${ }^{\circledR}$ UC30 digital camera and with a Leica ${ }^{\circledR}$ DMRX with bright field equipped with a Leica ${ }^{\circledR}$ DC500 camera.

For scanning electron microscopy (SEM) of Antarctic material, parts of the oxidized suspensions were filtered through a $1-\mu \mathrm{m}$ Isopore ${ }^{\mathrm{TM}}$ polycarbonate membrane filter (Merck Millipore). The stubs were sputter-coated with a gold-palladium layer of $20 \mathrm{~nm}$ and studied in a Zeiss Ultra SEM microscope at $3 \mathrm{kV}$ (Natural History Museum London, UK). SEM images of the material collected in Oregon (USA) were taken with an ultra-high-resolution analytical field emission (FE) scanning electron microscope Hitachi SU-70 (Hitachi High-Technologies Corporation, Japan) operated at $5 \mathrm{kV}$ and $10 \mathrm{~mm}$ distance (Public Research Centre - Gabriel Lippmann, Luxembourg). SEM images were taken using the lower (SE-L) detector signal.

Diatom terminology follows Ross et al. (1979) and Round et al. (1990). For comparison, the following publications were consulted: Schaarschmidt (1881), Cleve (1894), Müller (1909), Frenguelli (1923, 1930), Hustedt (1933), Cleve-Euler (1953), Patrick \& Reimer (1966), LangeBertalot \& Krammer (1989), Krammer \& Lange-Bertalot (1991), Lange-Bertalot (1997), Lange-Bertalot \& Genkal (1999), Potapova (2011).

Samples and slides are stored at the BR-collection (Botanic Garden Meise, Belgium).

\section{RESULTS AND DISCUSSION}

The identity of three species is here clarified (table 2). Planothidium haynaldii seems to be a rare species found in the Andes mountain range of South America (Ecuador, Chile), while Planothidium capitatum is mainly found in lakes in the Antarctic continent. Planothidium amphibium is the most common and widespread diatom among the three species here discussed and has been misidentified in the past 
Pl. Ecol. Evol. 147 (3), 2014

Table 2 - Morphological features of Planothidium amphibium, P. haynaldii and P. capitatum.

\begin{tabular}{|c|c|c|c|}
\hline reference & this study & Schaarschmidt (1881) & Müller (1909) \\
\hline central area & sinus & sinus & sinus \\
\hline length $(\mu \mathrm{m})$ & $11-21$ & $17-32$ & $15-22$ \\
\hline striae & $13-16$ & $14-16$ & $14-15$ \\
\hline valve shape & $\begin{array}{l}\text { valves linear to linear-lanceolate; } \\
\text { slightly to moderately swollen } \\
\text { in the middle portion }\end{array}$ & $\begin{array}{l}\text { valves linear to linear-lanceolate; } \\
\text { markedly swollen in the middle } \\
\text { portion }\end{array}$ & $\begin{array}{l}\text { valves linear to linear-lanceolate; } \\
\text { slightly expanded in the middle }\end{array}$ \\
\hline
\end{tabular}

as Planothidium haynaldii. Their identities are discussed as follows:

Planothidium haynaldii (Schaarschm.) Lange-Bert.

Fig. 2A-AJ

Basionym - Achnanthes haynaldii Schaarschm., Magyar Növénytani Lapok 5: 20. 1881 (Schaarschmidt 1881).

$\equiv$ Achnanthes lanceolata var. haynaldii (Schaarschm.) Cleve, Le Diatomiste 2: 99.1894 (Cleve 1894).

$\equiv$ Achnanthidium lanceolatum var. haynaldii (Schaarschm.) Comber, Catalogue of African Plants Collected by Dr. Friedrich Welwitsch 2: 389. 1901 (Comber 1901).

$\equiv$ Achnanthidium lanceolatum var. haynaldii (Schaarschm.) F.Meister, Die Kieselalgen der Schweiz. Beiträge zur Kryptogamenflora der Schweiz: 99.1912 (Meister 1912).

$\equiv$ Microneis lanceolata var. haynaldii (Schaarschm.) Freng., Boletín de la Academia Nacional de Ciencias en Córdoba 27: 73. 1923 (Frenguelli 1923).

$\equiv$ Achnanthidium haynaldii (Schaarschm.) Morosov, Visnik Dnipropetrovskoi Hidrobilogichnoi Stantsii 1: 68. 1929 (Morosov 1929).

$\equiv$ Achnantheiopsis haynaldii (Schaarschm.) Lange-Bert., Archiv für Protistenkunde 148: 207. 1997 (Lange-Bertalot 1997).

$\equiv$ Planothidium lanceolatum var. haynaldii (Schaarchm.) Bukht., Diatoms of Ukraine inland waters: 44.1999 (Bukhtiyarova 1999).

= Achnanthes looseri Freng., Revista Chilena de Historia Natural 34: 198, fig. 35-1. 1930 (Frenguelli 1930), synon. nov.

= Planothidium looseri (Freng.) P.Rivera \& Cruces, Gayana Botanica 66: 96, figs 1-2. 2009 (Rivera \& Cruces 2009), synon. nov.

Description - Valves linear to linear-lanceolate with convex margins and capitate (in larger cells) to subcapitate (smaller cells), protracted apices. Valve dimensions $(n=50)$ : length 17-32 $\mu \mathrm{m}$, width $6.7-9.5 \mu \mathrm{m}$. Cells strongly bent in connective view (fig. 2I). Rapheless valve (fig. $2 \mathrm{~A}-\mathrm{H}$ \& J-R): Axial area narrow and linear. Central area with a large horseshoe-shaped hyaline area on one side, showing a clear, hemicircular depression surrounded by a raised ridge (= sinus) (fig. 2A-R). On the other side, striae slightly shortened forming hence a small hemicircular central area on this side (fig. 2A). Fascia never observed. Striae weakly radiate almost throughout the entire valve, $14-16$ in $10 \mu \mathrm{m}$. Raphe valve (fig. 2S-AJ): Axial area narrow, linear, almost not widening towards the central area. Central area asymmetrical, rectangular to bow-tie shaped bordered on one side by $2-5$ irregularly shortened striae. Complete fascia never present. Raphe branches straight with simple proximal raphe endings. Distal raphe fissures unilaterally deflected, hard to observe in LM. Smaller valves can present slight 'cymbelloid' symmetry (fig. 2AC-AF). Striae radiate throughout the entire valve, becoming more distinctly radiate near the apices, $14-16$ in $10 \mu \mathrm{m}$.

Ecology and distribution - Planothidium haynaldii was described as an epiphytic aquatic species from Ecuador. The species is dominant in the sample collected at the Antisana volcano. The varieties described by Schaarschmidt (1881) correspond actually to a size reduction series of the same species. There are hardly any other species found in the assemblage. The most common one is Eunotia minor (Kütz.) Grunow, whereas single valves of Eolimna minima (Grunow) Lange-Bert. and Pinnularia borealis Ehrenb. were also found. Despite being mentioned in several different regions of the world according to the published literature, we could not identify any image that could correspond to the type material here observed.

Frenguelli (1930) described Achnanthes (Microneis) looseri from a 'trípoli' (rotten stone, a fine powdered porous rock, usually weathered limestone mixed with diatomaceous, amorphous, or crystalline silica) from Calama, Antofagasta, Chile (2260 m a.s.1.). Recently Rivera \& Cruces (2009) lectotypified the species and illustrated it with LM and SEM images. According to the authors Planothidium looseri has only been reported from Chilean localities. The species was 


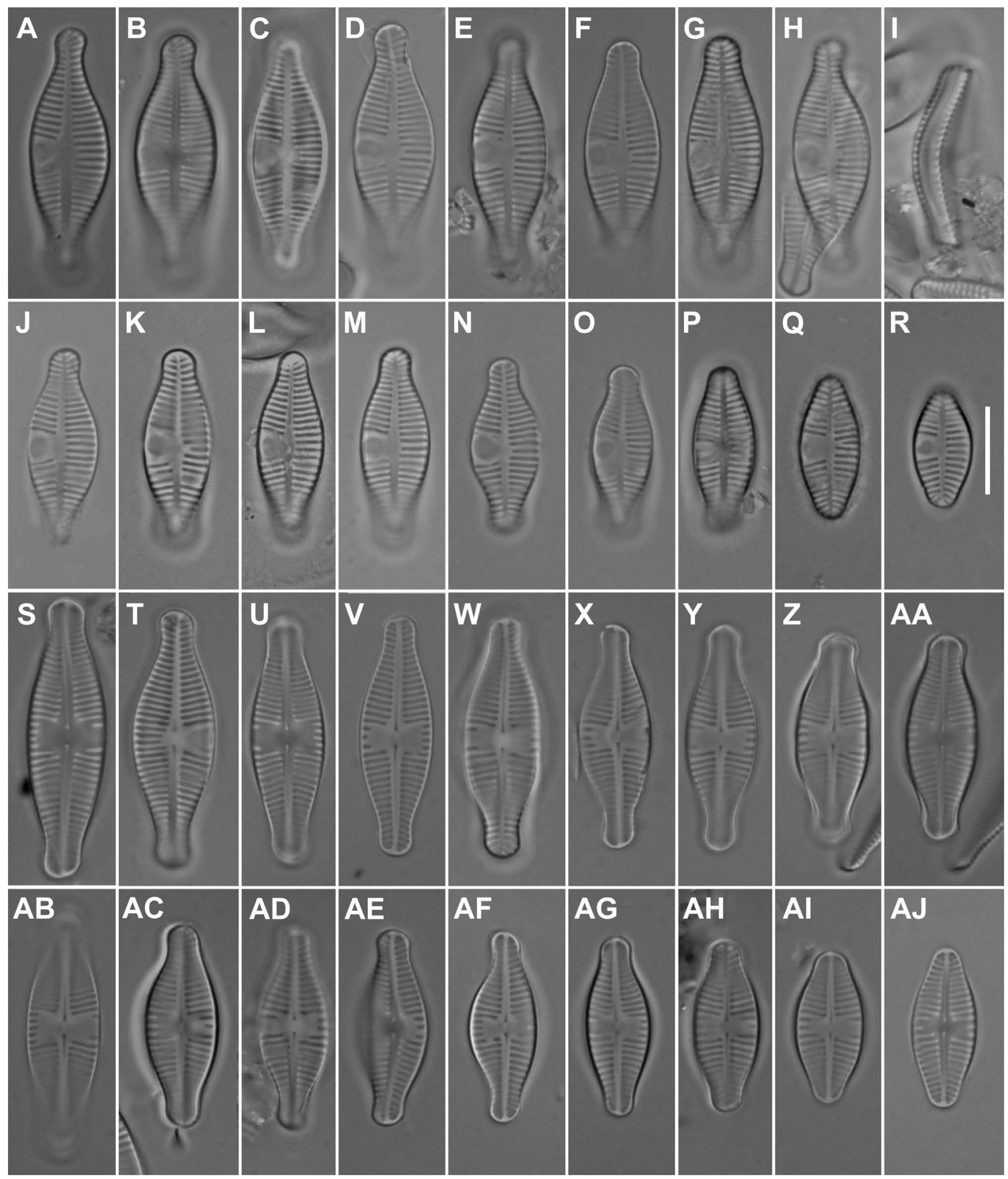

Figure 2 - Planothidium haynaldii LM: A-H, J-R, rapheless valves; I, girdle view, S-AJ, raphe valves. Specimens from the original slide (Ecuador, Antisana volcano). Scale bar represents $10 \mu \mathrm{m}$. 
also reported by Frenguelli (1934) in the trípoli of San Pedro de Atacama, Antofagasta, Chile. We consider here $P$. looseri as a synonym of $P$. haynaldii since all morphological characteristics (valve width, shape, stria density) are shared between both species. On the basis of our dataset, Planothidium haynaldii is only present in South America (Ecuadorian and Chilean localities at high altitude sites). Frenguelli (1935) also described a new variety Achnanthes looseri var. lanceolata, from Isla Cailín, Chiloé, Chile, which seems to be a rather distinct taxon but which needs more analysis before a clear conclusion can be drawn.

Planothidium amphibium C.E.Wetzel, Ector \& L.Pfister, sp. nov.

Figs $3 \mathrm{~A}-\mathrm{AS} \& 4 \mathrm{~A}-\mathrm{J}$
Type: holo-: BR-4384 (Botanic Garden Meise, Belgium) (here designated as the specimen illustrated in figures $3 \mathrm{M}$ and 3Y); iso-: PLP-269 (University of Antwerp, Belgium). - Type locality: Population collected in submerged green algae at the Oak Creek Watershed, Sheepfarm near Corvallis, Oregon, USA, $44^{\circ} 35^{\prime} 32.3^{\prime} \mathrm{N} 123^{\circ} 19^{\prime} 43.2^{\prime \prime} \mathrm{W}$, sample CRP1295 (leg. Laurent Pfister, coll. date 6 Mar. 2012).

Etymology - 'amphibius', living in water and on land; 'amphi-' from Greek: around, double, on both sides, of two kinds.

LM: description - Valves linear to linear-lanceolate with convex margins and capitate to subcapitate, protracted apices. Specimens at the small end of the size range are nearly elliptical. Valve dimensions $(\mathrm{n}=60)$ : length $11.0-21.0 \mu \mathrm{m}$

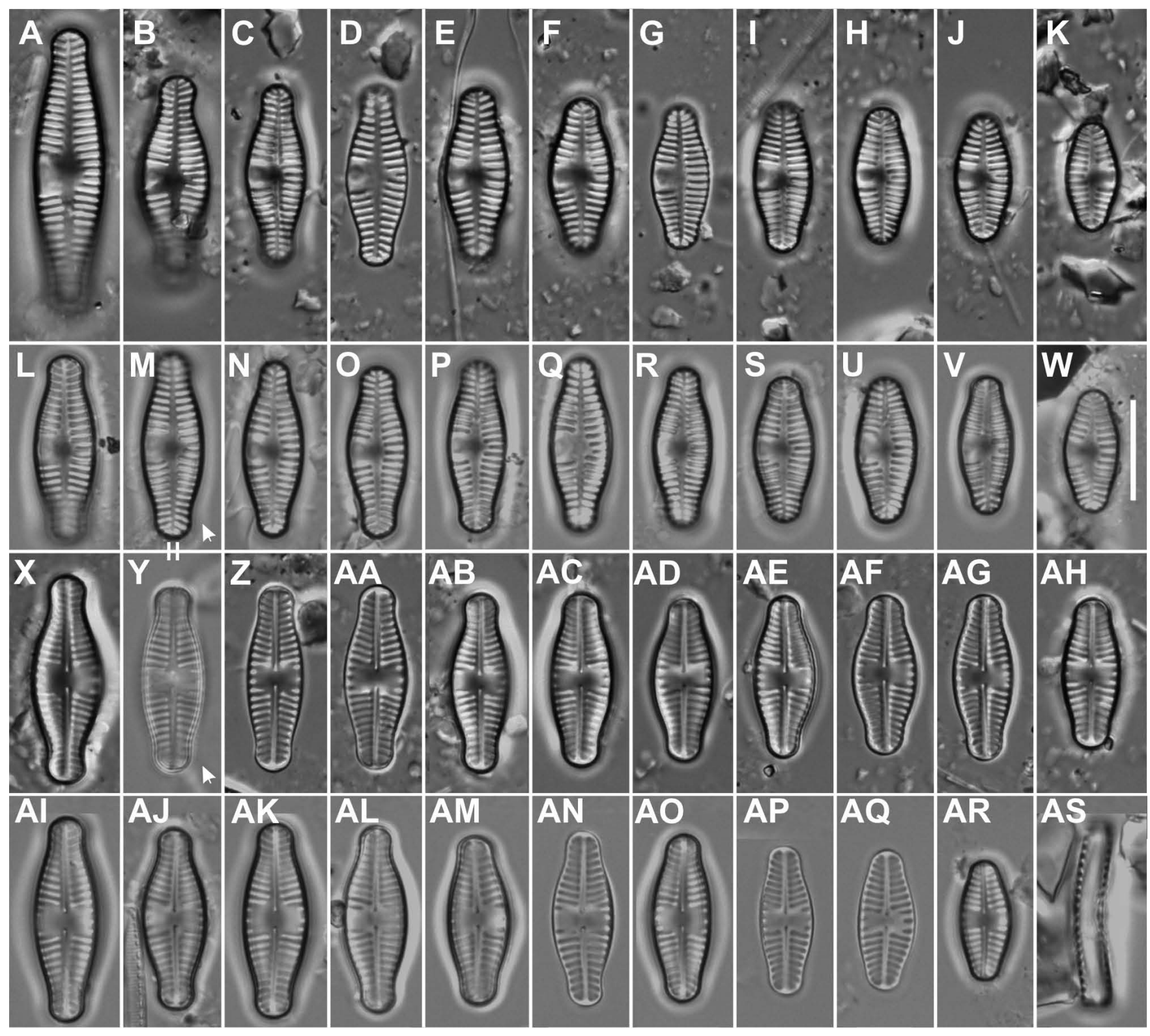

Figure 3 - Planothidium amphibium LM: A-W, rapheless valves; X-AR, raphe valves; AS, girdle view. Specimens from the type slide BR4384 (Botanic Garden Meise). Holotype specimen indicated (white arrows). Population collected in submerged green algae at the Oak Creek Watershed, located near Corvallis, Oregon, USA. Scale bar represents $10 \mu \mathrm{m}$. 


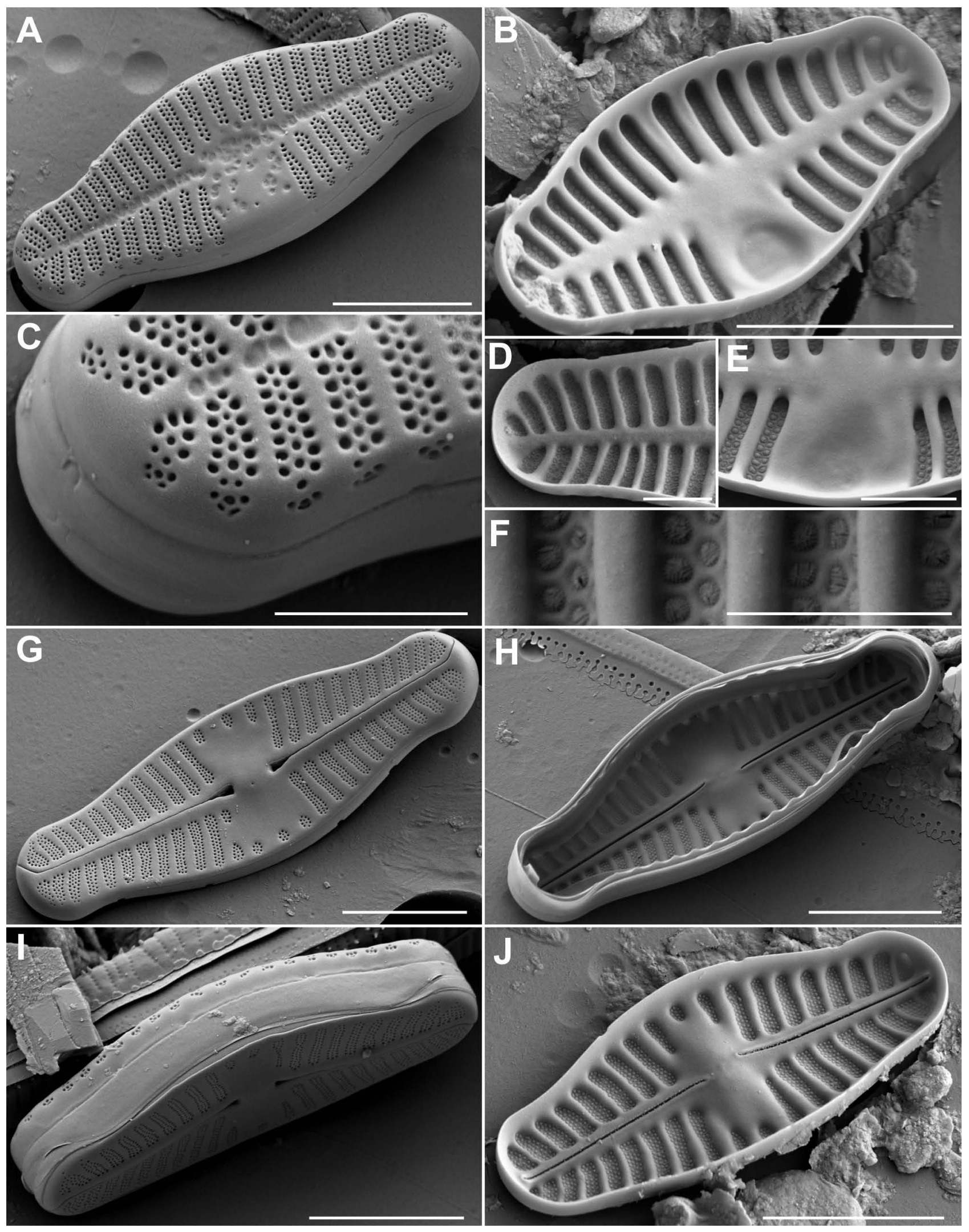

Figure 4 - Planothidium amphibium SEM: A-F, rapheless valve; A, external view; B, internal view; C, detail of apical striae and areolae; D, apical striae and raised virgae; E, detail of sinus depression; F, internal detail of areolae; G-J, raphe valve; G, external view; H, internal view; I, tilted view of a complete frustule with unperforated open girdle bands; J, internal view. Population from Oak Creek Watershed, Oregon, USA. Scale bars: A-B, G-J $=5 \mu \mathrm{m}, \mathrm{C}-\mathrm{E}=2 \mu \mathrm{m}, \mathrm{F}=1 \mu \mathrm{m}$. 
(max $27.9 \mu \mathrm{m}$ ), width 5.0-6.0 $\mu \mathrm{m}$. Rapheless valve (fig.3A$\mathrm{W})$ : Axial area narrow, linear, weakly but gradually widening towards the central area. Central area with a large horseshoe-shaped hyaline area on one side, showing a clear, hemicircular depression surrounded by a raised ridge. On the other side, striae shortened forming hence a small hemicircular central area on this side. Fascia never observed. Striae weakly radiate almost throughout the entire valve, becoming distinctly radiate near the apices, 13-16 in $10 \mu \mathrm{m}$. Raphe valve (fig. 3X-AS): Axial area very narrow, linear, not widening towards the central area. Central area asymmetrical, rectangular to bordered by 2-3 clearly shortened striae but never entirely lacking. Complete fascia never present. Raphe branches straight with simple proximal raphe endings. Distal raphe fissures unilaterally deflected, hard to observe in LM. Striae radiate throughout the entire valve, becoming more distinctly radiate near the apices, $14-16$ in $10 \mu \mathrm{m}$.

SEM: description, external and internal view - Striae of the rapheless valve composed of three rows of small rounded areolae (fig. 4A-F), occasionally with a fourth row of very small areolae interposed between larger areolae (fig. 4C). Near the central area, striae often with the middle row having smaller areolae (fig. 4A). Striae continuing shortly on the valve mantle (fig. 4C). Areolae covered by individual perforated hymenes (fig. 4D-F). Horseshoe-shaped sinus clearly present on the rapheless valve, forming a deep circular depression on one side of the central area, surrounded by a thickened silica ridge (fig. 4B, 4E). Cavum never present. Raphe valve shows striae slightly broader than the virgae, composed of three to four rows of rounded areolae (fig. $4 \mathrm{G}, 4 \mathrm{I}$ ), the central two rows composed of smaller areolae than the outer rows. Near the central area, usually three or two rows of shorter striae (fig. 4G). Raphe branches straight to weakly undulating (fig. 4G). Proximal raphe endings unilaterally weakly deflected terminating in simple pores, surrounded by a shallow spathulate depression (fig. 4G-4J). Distal raphe fissures clearly bent, continuing shortly onto the valve mantle (fig. 4G), opposite to the proximal endings. Internally, striae clearly sunken between raised virgae (fig. $4 \mathrm{H}$, 4J). Central nodule only weakly raised (fig. 4H). Proximal raphe endings terminating inconspicuously deflected to opposite sides (fig. $4 \mathrm{H}$ ). Distal raphe endings terminating on small helictoglossae (fig. 4J).

Taxonomical remarks - Planothidium amphibium is closely related to Planothidium haynaldii by general valve outline, but differs from it mainly by having smaller cells. The main difference concerns the valve width. On the basis of the pictures and descriptions, the identification as Planothidium haynaldii in many floristic and taxonomic papers (see discussion) should be considered as belonging to Planothidium amphibium.

Planothidium amphibium is also closely related to Planothidium lanceolatum (Bréb. ex Kütz.) Lange-Bert. (Straub 1985, Van de Vijver et al. 2013) but differs by having always a wide protracted subcapitate to capitate end. Planothidium biporomum (M.H.Hohn \& Hellerman) Lange-Bert., P. incuriatum C.E.Wetzel, Van de Vijver \& Ector and $P$. bagualense C.E.Wetzel \& Ector are similar species concerning general dimensions and valve shape, but differ from P. amphibium by having a cavum instead of a sinus as recently described by Wetzel et al. (2013) and Wetzel \& Ector (2014).

Achnanthes semifasciata (Østrup) M.Møller in Foged is a similar species but the type slide illustrated by Foged (1974, plate 36 , fig. 12a,b) from Iceland presents a larger specimen more similar to $P$. haynaldii. The species was originally described as Navicula semifasciata Østrup (Østrup 1918: 28, plate 3, fig. 41) and presents larger dimensions and thus a synonymization with $P$. amphibium should be discarded. Florin (1944: 425, fig. 3a-c) illustrated a new form A. haynaldii f. semiaperta Florin having a unilateral expansion on the raphe valve, which is not observed in P. amphibium.

Ecology and distribution - Planothidium amphibium was registered as a dominant species in several samples collected in Oregon (USA). Indeed the species reached between 10 to $28 \%$ of relative abundance in moist terrestrial habitats, such as soil samples collected in grassland prairies of the riparian zone (including bryophytes and herbaceous vegetation). In drift (water) samples the relative abundance of $P$. amphibium increased with discharge and the amount of rainfall observed in the catchment (fig. 5). During the rainfall storm event the species reached $43 \%$ of the diatom assemblage $(\mathrm{min} .=$ $6.7 \%$, mean $=22.3 \%, \pm 8.3, \mathrm{n}=27$ ). The relative abundance during the rainfall event fluctuated between $30-43 \%$ (fig. 5). Common species found associated with P. amphibium were Fragilariforma nitzschioides (Grunow) Lange-Bert., Diploneis cf. separanda Lange-Bert., Gomphonema micropus Kütz., Nitzschia cf. hantzschiana Rabenh., Planothidium lanceolatum, Eolimna tantula (Hust.) Lange-Bert., Gomphonema duplipunctatum Lange-Bert. \& E.Reichardt and $\mathrm{Me}$ ridion constrictum Ralfs.

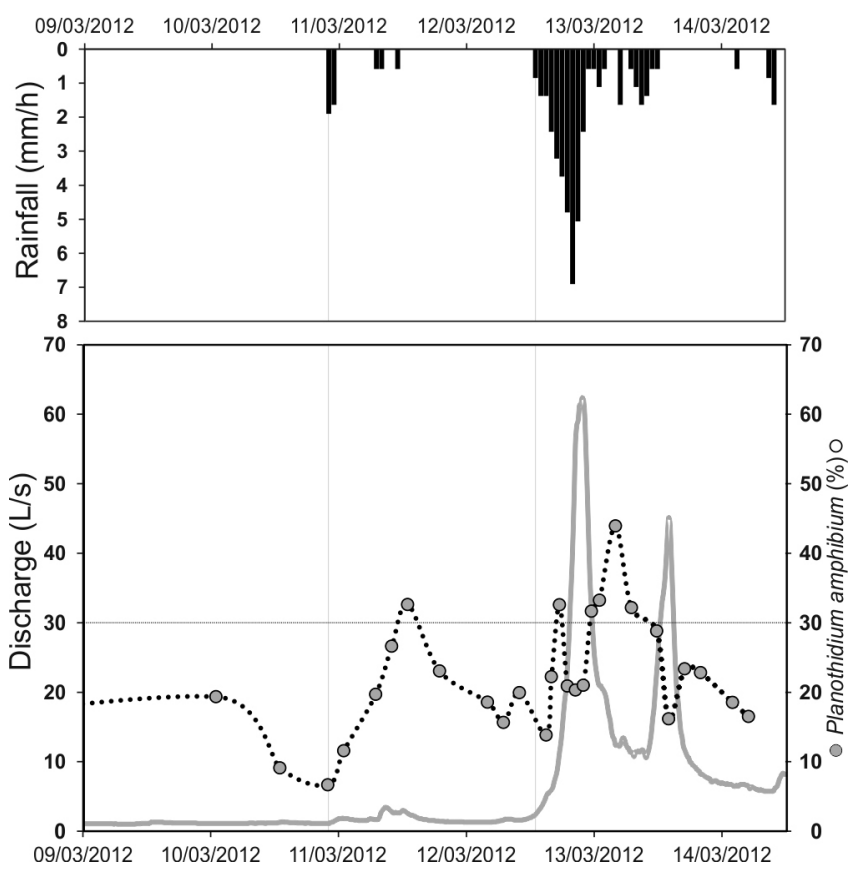

Figure 5 - Precipitation and discharge data from Oak Creek Watershed, Oregon, USA for the 9 to 14 Mar. 2012 period. Grey dots correspond to relative abundance of Planothidium amphibium. 
Indeed Otte \& Bellis (1985) have also observed the ability of "A. haynaldii" (most probably P. amphibium) to live in a soil marsh system in North Carolina associated with other edaphic diatoms. According to the categories of van Dam et al. (1994), P. amphibium should be considered a subaerial alkaliphilous species (mainly occurring at $\mathrm{pH}>7$ ). The water from the Oak Creek could be classified as moderately soft with calcium hardness ranging between 16.7 and $42.2 \mathrm{mg} . \mathrm{L}^{-1}$ $\mathrm{CaCO}_{3}$. The species seems to be rarer and even occasional (e.g. Blanco et al. 2008, Barinova \& Tavassi 2009, Falasco \& Bona 2011, Novais et al. 2014) compared to P. lanceolatum; it can reach higher abundances in Russia (Kulikovskiy et al. 2010, Hoff et al. 2014) and North America (i.e. Lowe \& Cody 2002). According to Lowe \& Cody (2002) individuals often occur regularly in samples that are collected from cooler, clear water of the northern USA and when present, they usually co-occur with Planothidium lanceolatum.

However, ecological information gathered from the literature is quite sparse and precise details about the ecological requirements of the species are still poorly known.

As previously mentioned Planothidium amphibium is the most common diatom amongst the species here discussed and has been misidentified in the past as Planothidium haynaldii ( $\equiv$ Achnanthes haynaldii, $\equiv$ Achnanthes lanceolata var. haynaldii, $\equiv$ Planothidium lanceolatum var. haynaldii) from a wide range of ecozones (fig. 6) including:

Paleartic (i.e. Terry 1908, Meister 1912, Kaiser 1916, Steinecke 1916, Héribaud 1920, Cholnoky 1922, Rich 1925, Budde 1929, Szemes 1931, 1960, Bastow 1949, Topachevsky \& Oksiyuk 1960, Robinson 1982, Hartley 1986, Lange-Bertalot \& Krammer 1989, Wendker
1990, Pastor 1991, Medvedeva 1994, 1995, 1999, 2001, Müllner 1995, Laugaste \& Pork 1996, Temniskova-Topalova \& Ognjanova-Rumenova 1997, Bukhtiyarova 1999, 2007, 2008, Lange-Bertalot \& Genkal 1999, Balbi 2000, Nikulina 2001, 2003, 2005, 2006, 2008, 2010a, 2010b, 2011, 2014, Pierre 2001, Kawecka 2003, 2012, Karayeva \& Dzhafarova 2004, Medvedeva \& Barinova 2004, Barinova et al. 2005, 2010, Korol 2005, Novoveska 2005, Reiter \& Burchardt 2005, Savateev \& Medvedeva 2005, Shevchenko 2007, Blanco et al. 2008, 2010, Barinova \& Tavassi 2009, Tsarenko et al. 2009, Kulikovskiy et al. 2010, Falasco \& Bona 2011, Hoff et al. 2011, 2014, Medvedeva \& Miski 2011, Nikulina \& Kociolek 2011, Soltanpour-Gargari et al. 2011, Turskaya 2011, Genkal et al. 2012, Gorokhova et al. 2012, Lai et al. 2014, Novais et al. 2014);

- Neartic (i.e. Tempère \& Peragallo 1915, McIntire 1968, Moore 1972, 1981, Bacon \& Taylor 1976, Duthie \& Socha 1976, Otte \& Bellis 1985, Mattson et al. 1995, Andrle \& Kingston 1998, Stoermer et al. 1999, Camburn \& Charles 2000, Kellogg \& Kellogg 2002, Kociolek 2005, Eberle 2008, Bogan et al. 2012);

- Antarctic (i.e., Schmidt et al. 1990, Oppenheim 1994, Unrein \& Vinocur 1999, Unrein 2000, Vinocur \& Pizarro 2000, Vinocur \& Unrein 2000, Unrein et al. 2005, Van de Vijver et al. 2010, Kopalová \& Van de Vijver 2013, Rochera et al. 2013, Kopalová et al. 2014);

- Indomalayan (i.e. Hustedt 1927, Amossé 1969, Asai 1995, Lee et al. 1995, Shiono \& Jordan 1995, Peerapornpisal et al. 2000);

- Afrotropic (i.e. Comber 1901, Müller 1910, Woodhead \&

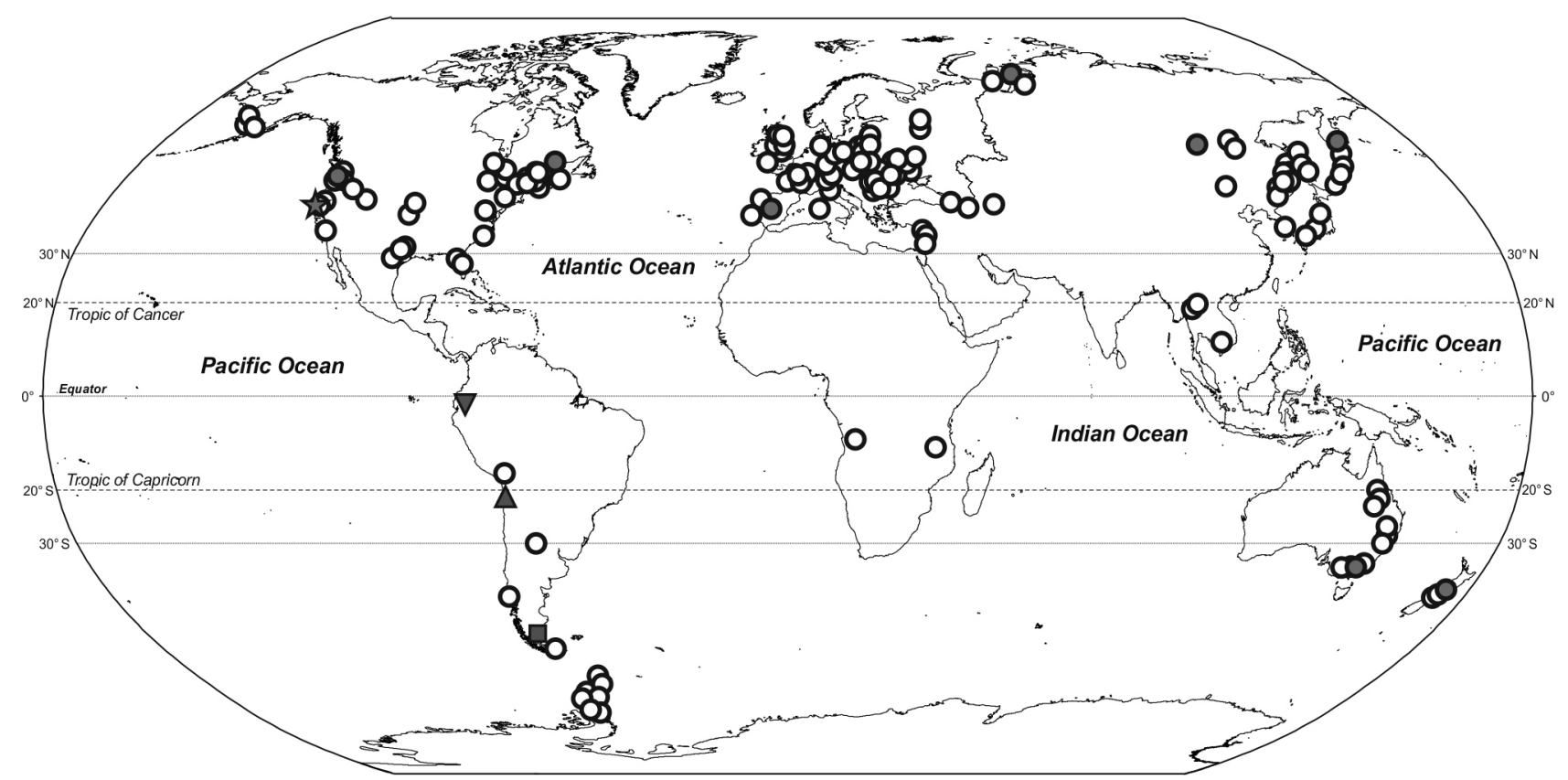

Figure 6 - Distribution records of Planothidium haynaldii ( $\equiv$ Achnanthes haynaldii, $\equiv$ Achnanthes lanceolata var. haynaldii, $\equiv$ Planothidium lanceolatum var. haynaldii) with illustration (grey dots) and without (white dots) according to the literature; most of these records probably belong to the new species Planothidium amphibium. Type localities of P. amphibium (grey star), Oak Creek Watershed, Oregon, USA, P. haynaldii (grey inverted triangle), Antisana volcano, Ecuador; Planothidium looseri (grey triangle), Calama, Antofagasta, Chile and Planothidium capitatum (三Achnanthes lanceolata var. capitata) (grey square), South Patagonia, Argentina, are indicated as well. 
Tweed 1958);

- Neotropic (i.e. Maidana et al. 2005, Morales et al. 2009); Australasian (Foged 1978, Schowe 2012, Schowe \& Harding 2014).

Although extensive, the majority of records do not provide images to confirm the distribution of the species. Illustrated and confirmed records of Planothidium amphibium (as P. haynaldii or A. haynaldii) (fig. 6, grey dots) are those from Australia (Foged 1978, plate 15, fig. 8, as Achnanthes lanceolata (Bréb.) Grun. f. capitata O.Müll.), Canada (Reavie \& Smol 1998, plate 12, fig. 9, as Achnanthes lanceolata var. rostrata (Østrup) Hust.), Siberia (Lange-Bertalot \& Genkal 1999, plate 9, fig. 11), USA (Lowe \& Cody 2002, figs 3037), Spain (Blanco et al. 2010, plate 45, figs 1-6, as Planothidium aff. lanceolatum), northern Mongolia (Kulikovskiy et al. 2010, plate 41, figs 10-13), New Zealand (Schowe 2012: 19, fig. 2.4) and Kamchatka (Hoff et al. 2014: 28, figs 3-22). Morales et al. (2009) observed $P$. haynaldii as the second most important species in terms of relative abundance in several rivers and streams of cloud forest and alpine streams in Bolivia; our personal observations confirm the presence of P. amphibium also in this country of South America. Records from the African continent lack illustrations and for several other citations, further confirmation is needed.

Planothidium capitatum (O.Müll.) Van de Vijver, Kopalová, C.E. Wetzel \& Ector, comb. \& stat. nov.

Fig. 7A-Z

Basionym - Achnanthes lanceolata var. capitata O.Müll., Botanische Jahrbücher für Systematik, Pflanzengeschichte und Pflanzengeographie 43 (Heft 4, Beiblatt Nr. 100): 8. 1909 (Müller 1909). - Type: South Patagonia (South America).

LM: description - Valves linear to linear-lanceolate with convex margins and capitate to subcapitate, protracted apices. Valve dimensions $(\mathrm{n}=30)$ : length $15.0-22.0 \mu \mathrm{m}$, width $4.5-5.0 \mu \mathrm{m}$. Rapheless valve (fig. 7C-L): Axial area narrow, $1 / 10$ of the total valve width, linear, weakly but gradually widening towards the central area. Central area with a large horseshoe-shaped hyaline area on one side, showing a clear, hemicircular depression surrounded by a raised ridge. On the other side, striae shortened forming hence a small hemicircular central area on this side. Fascia never observed. Striae weakly radiate almost throughout the entire valve, becoming distinctly radiate near the apices, $14-15$ in $10 \mu \mathrm{m}$. Raphe valve (fig. $7 \mathrm{M}-\mathrm{U}$ ): Axial area narrow, less than $1 / 10$ of total valve width, linear, almost not widening towards the central area. Central area asymmetrical, rectangular to bow-tie shaped bordered on one side by $2-3$ clearly shortened striae, while striae on the other side usually entirely lacking. Complete fascia never present. Raphe branches straight with simple proximal raphe endings. Distal raphe fissures unilaterally deflected, hard to observe in LM. Striae radiate throughout the entire valve, becoming more distinctly radiate near the apices, $14-15$ in $10 \mu \mathrm{m}$.

SEM: description, external and internal view - Striae of the rapheless valve composed of three rows of small rounded areolae (fig. 7W), occasionally with a fourth row of very small areolae interposed between larger areolae. Near the central area, striae often with the middle row having smaller areolae (fig. 7W). Striae continuing shortly on the valve mantle (fig. $7 \mathrm{~W}$ ). Striae of the raphe valve broader than the virgae, composed of four rows of rounded areolae (fig. 7X), the central two rows composed of smaller areolae than the outer rows. Near the central area only three, occasionally even two rows of areolae. Raphe branches straight to weakly undulating (fig. 7X). Proximal raphe endings unilaterally weakly deflected terminating in simple pores, surrounded by a shallow spathulate depression (fig. 7X). Distal raphe fissures clearly bent, continuing shortly onto the valve mantle (fig. 7X), opposite to the proximal endings. Internally, striae clearly sunken between raised virgae (fig. $7 \mathrm{Y}-\mathrm{Z}$ ). Areolae covered by individual perforated hymenes. Horseshoe-shaped sinus clearly present on the rapheless valve, forming a deep circular depression on one side of the central area, surrounded by a thickened silica ridge (fig. 7Y). Cavum never present. Central nodule only weakly raised (fig. 7Z). Proximal raphe endings terminating inconspicuously deflected to opposite sides (fig. 7Z). Distal raphe endings terminating on small helictoglossae. Shallow depressions present in the central area (fig. 7Z).

Taxonomical remarks - Originally described in the genus Achnanthes, the taxon should be transferred to Planothidium because it presents solitary, heterovalvar cells, with a slightly concave raphe valve and a convex rapheless valve. The valves present multiseriate striae and a horseshoe-shaped structure located in the central area (a shallow rimmed depression) called a sinus, absent in the genus Achnanthes sensu stricto. First described as a variety of Achnanthes lanceolata by Müller, the taxon should be considered as a separate species mainly due the unilateral lack of striae in the central area never observed in the type material of $P$. lanceolatum or any related species (see Van de Vijver et al. 2013). Planothidium capitatum is very closely related to Planothidium haynaldii and $P$. amphibium, but differs from both by showing slender valves and the unilateral lack of striae in the raphe valve.

Ecology and distribution - So far P. capitatum has been found in several localities in the Maritime Antarctic Region. Its presence is confirmed from the South Shetland Islands (Livingston Island, Deception Island, King George Island) and James Ross Island from our own observations. Müller (1909) also reports this taxon from Patagonia. Large populations were found on James Ross Island and Livingston Island, usually reported under the name of $P$. cf. haynaldii or $P$. haynaldii (Van de Vijver et al. 2010, Kopalová \& Van de Vijver 2013, Kopalová et al. 2014). The largest populations on Ulu Peninsula (James Ross Island) were found living in the epilithon and epipelon of larger lakes with a slightly to clearly alkaline $\mathrm{pH}(7.7-8.9)$ and low to moderate specific conductance levels $\left(75-250 \mu \mathrm{S} \mathrm{cm}^{-1}\right)$. The species has so far not been reported from the sub-Antarctic Region and the Antarctic Continent (Kellogg \& Kellogg 2002, Van de Vijver et al. 2002). Unrein \& Vinocur (1999) highlighted that Achnanthes lanceolata var. haynaldii was a dominant species throughout summer in the Tres Hermanos Lake, Potter Peninsula, King George Island (Antarctica) and that it was responsible for the density peaks recorded in early summer conditions in phytoplankton assemblages. However, the identity of this taxon 


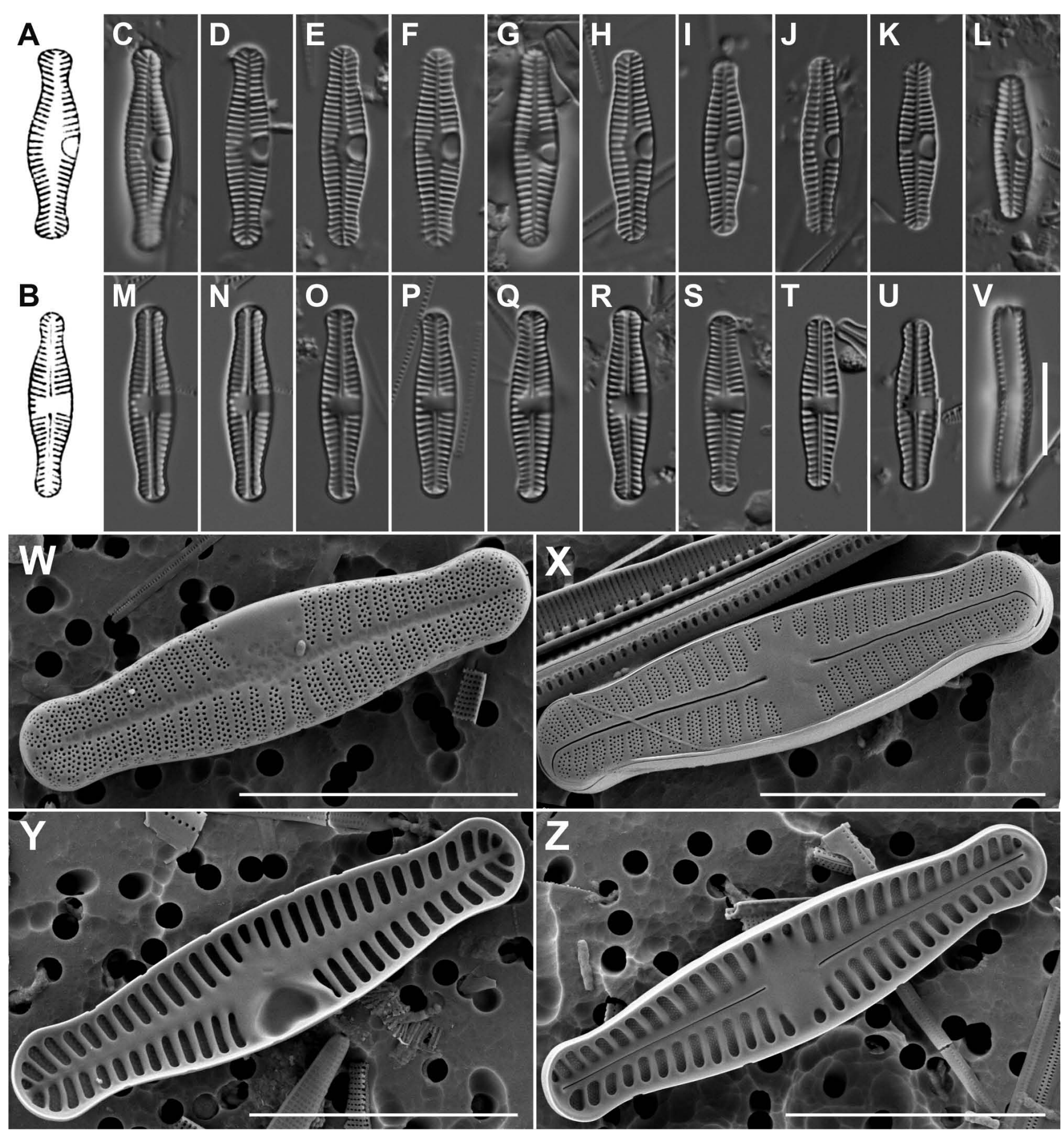

Figure 7 - Planothidium capitatum LM and SEM: A-B, original drawings of Achnanthes lanceolata var. capitata by Müller (1909: 8, plate 1, figs 6-7); LM: C-L, rapheless valves; M-U, raphe valves; V, girdle view. SEM: W, rapheless valve external view; X, external view of raphe valve; Y, internal view of rapheless valve; Z, internal view of raphe valve. C-Z: Population from Green Lake 2, Ulu Peninsula, James Ross Island. Scale bars represent $10 \mu \mathrm{m}$. 
is uncertain and should most probably be attributed to Planothidium capitatum.

\section{ACKNOWLEDGEMENTS}

This paper is dedicated to our colleague Pierre Compère (Botanic Garden Meise, Belgium) for his long dedication to algae, especially diatoms. We thank Marianne Hamnede (Swedish Museum of Natural History, Stockholm) for sending us the material and the original type slide of Achnanthes haynaldii Schaarschm. Funding for this research was provided by the Luxembourg National Research Fund (FNR) in the framework of the BIGSTREAM project (C09/SR/14) and TAXODIA project (Public Research Centre - Gabriel Lippmann, Belvaux, Luxembourg). Samples on Byers Peninsula were taken in the framework of the IPY-Limnopolar Project POL2006-06635 (Ministerio de Ciencia y Tecnología, Spain). The authors would also like to thank the members of expeditions to the Czech J.G. Mendel Antarctic Station for field support and assistance on James Ross Island. Part of the research was funded within the Belspo CCAMBIO project and an EU Synthesys grant to BVDV to visit the National History Museum in London, UK. Alex Ball, the staff of the IAC laboratory and Eileen J. Cox at the Natural History Museum are thanked for their help with the scanning electron microscopy. Marina Potapova, Saúl Blanco and an anonymous reviewer are gratefully acknowledged for suggestions and corrections on the manuscript.

\section{REFERENCES}

Amossé A. (1969) Note sur des diatomées récoltées en Indochine. Revue algologique, Nouvelle Série 9: 326-344.

Andrle V.A.S., Kingston J.C. (1998) Planothidium species in rivers and lakes of the United States. Abstracts of the 10th Annual U.S. Geological Survey, Central Region, 1998 Poster Review. Collected Abstracts of Selected Poster. Papers Presented at Scientific Meetings. Compiled by Modreski P. J. Open-File Report 98-209: 1. Denver, U.S. Geological Survey.

Asai K. (1995) Statistic classification of epilithic diatom species into three ecological groups relating to organic water pollution. (1) Method with coexistence index. Diatom 10: 13-34.

Bacon G.B., Taylor A.R.A. (1976) Succession and stratification in benthic diatom communities colonizing plastic collectors in a Prince Edward bland estuary. Botanica Marina 19: 231-240.

Balbi D.M. (2000) Phytoplankton dynamics of the River Nene, England. PhD thesis, Durham University, Durham, England. http://etheses.dur.ac.uk/4281/

Barinova S., Tavassi M. (2009) Study of seasonal influences on algal biodiversity in the River Yarqon (central Israel) by bioindication and canonical correspondence analysis (CCA). Turkish Journal of Botany 33: 353-372. http://dx.doi.org/10.3906/ bot-0812-12

Barinova S.S., Anissimova O.V., Nevo E., Wasser S.P. (2005) Diversity and ecology of phytoplankton and periphyton of the Nahal Oren, Alon Natural Park, Northern Israel. Algological Studies 116: 171-199. http://dx.doi.org/10.1127/18641318/2005/0116-0171

Barinova S.S., Yehuda G., Nevo E. (2010) Comparative analysis of algal communities in the rivers of northern and southern Israel as bearing on ecological consequences of climate change.
Journal of Arid Environments 74: 765-776. http://dx.doi. org/10.1016/j.jaridenv.2009.03.001

Bastow R.F. (1949) A note on the fresh-water diatoms of Devon. Journal of the Quekett Microscopical Club, ser. 4, 2(6): 304.

Blanco S., Ector L., Huck V., Monnier O., Cauchie H.M., Hoffmann L., Bécares E. (2008) Diatom assemblages and water quality assessment in the Duero basin (NW Spain). Belgian Journal of Botany 141: 39-50.

Blanco S., Cejudo-Figueiras C., Álvarez-Blanco I., Bécares E., Hoffmann L., Ector L. (2010) Atlas de las Diatomeas de la cuenca del Duero / Diatom Atlas of the Duero Basin. León, Área de Publicaciones, Universidad de León.

Bogan D., Shaftel R., Rinella D. (2012) Baseline biological surveys in wadeable streams of the Kvichak and Nushagak Watersheds, Bristol Bay, Alaska. Anchorage, Alaska, Alaska Department of Environmental Conservation.

Budde H. (1929) Beitrag zur Algenflora der fließenden Gewässer Spaniens. Archiv für Hydrobiologie 20: 427-470.

Bukhtiyarova L.N. (1999) Diatoms of Ukraine inland waters. Kiev, National Academy of Sciences of Ukraine, M.G. Kholodny Institute of Botany.

Bukhtiyarova L.N. (2007) To revision on the genus Achnanthes s. lato (Bacillariophyta). 2. New monoraphid genera and key to their determination. Algologia 17: 492-513 [in Russian].

Bukhtiyarova L.N. (2008) Revision of the genus Achnanthes Bory s. lato (Bacillariophyta). 2. New monosutural genera and the key for their identification. International Journal of Algae 10: 50-72. http://dx.doi.org/10.1615/InterJAlgae.v10.i1.50

Camburn K.E., Charles D.F. (2000) Diatoms of low-alkalinity lakes in the Northeastern United States. The Academy of Natural Sciences of Philadelphia. Special publication 18: 1-152.

Cholnoky B. (1922) Adatok Budapest Bacillariea-inak elterjedése ismeretéhez. Botanikai Közlemények 20(1-3): 66-79.

Chown S.L., Convey P. (2007) Spatial and temporal variability across life's hierarchies in the terrestrial Antarctic. Philosophical Transactions of the Royal Society, series B Biological Sciences 362: 2307-2331. http://dx.doi.org/10.1098/rstb.2006.1949

Cleve P.T. (1894) Les diatomées de l'Equateur. Le Diatomiste 2(18): 99-103, plate 7.

Cleve-Euler A. (1953) Die Diatomeen von Schweden und Finnland. Part III. Monoraphideae, Biraphideae 1. Kongliga Svenska Vetenskaps-Akademiens Handligar, ser. 4, 4(5): 1-255, figs 484-970.

Comber T. (1901) Diatomaceae. In: Catalogue of African Plants Collected by Dr. Friedrich Welwitsch in 1853-61. Volume 2, Part 2. Cryptogamia: 382-395. London, British Museum (Natural History).

Duthie H.C., Socha R. (1976) A checklist of the freshwater algae of Ontario, exclusive of the Great Lakes. Le Naturaliste Canadien 103: 83-109.

Eberle M.E. (2008) Recent diatoms reported from the Central United States: Register of taxa and synonyms. Lawrence, Kansas, USA, State Biological Survey of Kansas, Report Number 77: $1-83$.

Falasco E., Bona F. (2011) Diatom community biodiversity in an Alpine protected area: a study in the Maritime Alps Natural Park. Journal of Limnology 70: 157-167. http://dx.doi. org/10.4081/jlimnol.2011.157

Florin M.-B. (1944) En sensubarktisk transgression i trakten av södra Kilsbergen enligt diatomacésuccessionen i områdets högre belägna fornsjölagerföljder. Geologiska Föreningens 
i Stockholm Förhandlingar 66(3): 417-448. http://dx.doi. org/10.1080/11035894409445687

Foged N. (1974) Freshwater diatoms in Iceland. Bibliotheca Phycologica 15: 1-118.

Foged N. (1978) Diatoms in Eastern Australia. Bibliotheca Phycologica 41: 1-148.

Frenguelli J. (1923) Contribuciones para la sinopsis de las diatomeas Argentinas. I. Diatomeas del Río Primero en la ciudad de Córdoba. Boletín de la Academia Nacional de Ciencias de Córdoba 27: 13-119, 9 plates.

Frenguelli J. (1930) Diatomeas contenidas en una muestra de trípoli de Calama, en Chile. Revista Chilena de Historia Natural 34: 195-199.

Frenguelli J. (1934) Diatomeas del trípoli de San Pedro de Atacama. Revista Chilena de Historia Natural 38: 159-163.

Frenguelli J. (1935) Analisis diatomológico de trípolis chilenos. Revista Chilena de Historia Natural 39: 147-152.

Genkal S.I., Schur L.A., Yarushina M.I. (2012) Diatom algae from some water bodies of northeastern West Siberia: Communication 2. Pennatophyceae. Contemporary Problems of Ecology 5: 263-274. http://dx.doi.org/10.1134/S1995425512030055

Gorokhova O.G., Popchenko I.I., Korneva L.G., Genkal S.I., Pautova V.N. (2012) Addition to taxonomic list of phytoplankton of Ivankovo Reservoir (Russia). Algologia 22: 91-101.

Hartley B. (in collaboration with Ross R. \& Williams D.M.) (1986) A check-list of the freshwater, brackish and marine diatoms of the British Isles and adjoining coastal waters. Journal of the Marine Biological Association of the United Kingdom 66: 531610. http://dx.doi.org/10.1017/S0025315400042235

Héribaud J. (1920) Les diatomées des travertins d'Auvergne. Annales de Biologie Lacustre 10: 5-206.

Hoff U., Lange-Bertalot H., Diekmann B. (2011) Fragilaria flexura sp. nov. (Bacillariophyceae) - A new freshwater diatom from a meso-oligotrophic mountain lake on the Kamchatka Peninsula, Russia. Nova Hedwigia 92: 441-451. http://dx.doi. org/10.1127/0029-5035/2011/0092-0441

Hoff U., Dirksen O., Dirksen V., Kuhn G., Meyer H., Diekmann B. (2014) Holocene freshwater diatoms: palaeoenvironmental implications from south Kamchatka, Russia. Boreas 43: 22-41. http://dx.doi.org/10.1111/bor.12019

Hustedt F. (1927) Bacillariales aus dem Aokikosee in Japan. Archiv für Hydrobiologie 18: 155-172.

Hustedt F. (1933) Die Kieselalgen Deutschlands, Österreichs und der Schweiz unter Berücksichtigung der übrigen Länder Europas sowie der angrenzenden Meeresgebiete. In: Rabenhorst L. (ed.) Kryptogamen Flora von Deutschland, Österreich und der Schweiz. Vol. 7, Teil 2, Lief 3: 321-432, figs 781-880. Leipzig, Akademische Verlagsgesellschaft m.b.h.

Kaiser P.E. (1916) Beiträge zur Kenntnis der Algenflora von Traunstein und dem Chiemgau. III. Verzeichnis. Kryptogamische Forschungen herausgegeben von der Kryptogamenkommission der Bayerischen Botanischen Gesellschaft zur Erforschung der Heimischen Flora 1: 30-38.

Karayeva N.I., Dzhafarova S.K. (2004) Diversity of diatoms (Bacillariophyta) in Azerbaijan. International Journal on Algae 6: 224-234. http://dx.doi.org/10.1615/InterJAlgae.v6.i3.20

Kawecka B. (2003) Effect of different light conditions on cyanobacteria and algal communities in Tatra mts stream (Poland). Oceanological and Hydrobiological Studies 32: 3-13.

Kawecka B. (2012) Diatom diversity of the lower part of the Sljudjanka river draining the Chamar-Daban Mountains (southern part of the Lake Baikal catchment, Siberia, Russia). In:
Wolowski K., Kaczmarska I., Ehrman J.M., Wojtal A.Z. (eds) Current advances in algal taxonomy and its applications: phylogenetic, ecological and applied perspective: 79-107. Kraków, W. Szafer Institute of Botany, Polish Academy of Sciences.

Kellogg T.B., Kellogg D.E. (2002) Non-marine and littoral diatoms from Antarctic and sub-Antarctic locations. Distribution and updated taxonomy. Diatom Monographs 1: 1-795.

Kociolek J.P. (2005) A checklist and preliminary bibliography of the recent, freshwater diatoms of inland environments of the continental United States. Proceedings of the California Academy of Sciences (Fourth Series) 56: 395-525.

Kopalová K., Van de Vijver B. (2013) Structure and ecology of freshwater benthic diatom communities from Byers Peninsula, Livingston Island, South Shetland Islands. Antarctic Science 25: 239-253. http://dx.doi.org/10.1017/S0954102012000764

Kopalová K., Nedbalová L., Nývlt D., Elster J., Van de Vijver B. (2013) Diversity, ecology and biogeography of the freshwater diatom communities from Ulu Peninsula (James Ross Island, NE Antarctic Peninsula). Polar Biology 36: 933-948. http:// dx.doi.org/10.1007/s00300-013-13T/-5

Kopalová K., Ochyra R., Nedbalová L., Van de Vijver B. (2014) Moss-inhabiting diatoms from two contrasting Maritime Antarctic islands. Plant Ecology and Evolution 147: 67-84. http:// dx.doi.org/10.5091/plecevo.2014.896

Korol G. (2005) Diatom flora from the Zhidini section and its palaeogeographic and biostratigraphic significance. Geologija 49: $29-39$.

Krammer K., Lange-Bertalot H. (1991) Bacillariophyceae 4. Teil: Achnanthaceae, Kritische Ergänzungen zu Navicula (Lineolatae) und Gomphonema Gesamtliteraturverzeichnis Teil 1-4. In: Ettl H., Gärtner G., Gerloff J., Heynig H., Mollenhauer D. (eds) Süsswasserflora von Mitteleuropa, vol. 2/4. Stuttgart \& New York, G. Fischer.

Kulikovskiy M.S., Lange-Bertalot H., Witkowski A., Dorofeyuk N.I., Genkal S.I. (2010) Diatom assemblages from Sphagnum bogs of the world I. Nur bog in northern Mongolia. Bibliotheca Diatomologica 55: 1-326.

Lai G.G., Padedda B.M., Virdis T., Sechi N., Lugliè A. (2014) Benthic diatoms as indicators of biological quality and physical disturbance in Mediterranean watercourses: a case study of the Rio Mannu di Porto Torres basin, northwestern Sardinia, Italy. Diatom Research 29: 11-26. http://dx.doi.org/10.1080/026924 9X.2013.851119

Lange-Bertalot H. (1997) Zur Revision der Gattung Achnanthes sensu lato (Bacillariophyceae): Achnantheiopsis, eine neue Gattung mit dem Typus generis A. lanceolata. Archiv für Protistenkunde 148: 199-208.

Lange-Bertalot H. (1999) Neue Kombinationen von Taxa aus Achnanthes Bory (sensu lato). Iconographia Diatomologica 6: 276289.

Lange-Bertalot H., Genkal S.I. (1999) Diatoms from Siberia I. Islands in the Arctic Ocean (Yugorsky-Shar Strait). Iconographia Diatomologica 6: 1-271.

Lange-Bertalot H., Krammer K. (1989) Achnanthes eine Monographie der Gattung mit Definition der Gattung Cocconeis und Nachträgen zu den Naviculaceae. Bibliotheca Diatomologica 18: 1-393.

Laugaste R., Pork M. (1996) Diatoms of Lake Peipsi-Pihkva: a floristic and ecological review. Hydrobiologia 338: 63-76. http:// dx.doi.org/10.1007/BF00031711

Lee K., Choi J.K., Lee J.H. (1995) Taxonomic studies on diatoms in Korea. II. Check-list. Korean Journal of Phycology (Suppl 10): 13-89 [in Korean]. 
Lowe R.L., Cody W.R. (2002) Planothidium rostratum (Østrup) Lange-Bertalot (Bacillariophyceae) and related species from North American streams and rivers. In: Morales E.A., Charles D.F. (eds) Tenth NAWQA Taxonomy Workshop on Harmonization of Algal Taxonomy June 13-15, 200263-87. Report No. 05-1F: 63-87. Philadelphia, Phycology Section/Diatom Analysis Laboratory, Patrick Center for Environmental Research, The Academy of Natural Sciences of Philadelphia.

Maidana N.I., Izaguirre I., Vinocur A., Mataloni G., Pizarro H. (2005) Diatomeas en una transecta patagónica-antártica. Ecología Austral 15: 159-176.

Mattson R.A., Epler J.H., Hein M.K. (1995) Description of benthic communities in karst, spring-fed streams of North Central Florida. Journal of the Kansas Entomological Society 68(2) Supplement: $18-41$.

McIntire C.D. (1968) Structural characteristics of benthic algal communities in laboratory streams. Ecology 49: 520-537. http://dx.doi.org/10.2307/1934118

Medvedeva L.A. (1994) Diatom algae of Serebryanka River basin (Sikhote-Alin reserve). Botanitcheskii Zhurnal 79: 46-56 [in Russian].

Medvedeva L.A. (1995) Sessile algae of the Kedrovaya stream and its tributaries (Prymorye Far East). Report of the studies on the structure and function of river ecosystems of the Far East 3: $13-19$.

Medvedeva L.A. (1999) Features of the phycoflora of Zeva River (Prymorye Territory). Biology of Inland Waters 1-3: 21-31 [in Russian]

Medvedeva L.A. (2001) Biodiversity of aquatic algal communities in the Sikhote-Alin biosphere reserve (Russia). Cryptogamie, Algologie 22: 65-100. http://dx.doi.org/10.1016/S01811568(00)01050-3

Medvedeva L.A., Barinova S.S. (2004) Presnovodnaye vodorosli nekotorayh vodoemov Habarovskogo kraya. Botanicheskii Zhurnal 89: 1768-1782.

Medvedeva L.A., Miski A.V. (2011) Materials on the flora of freshwater algae from western coast of Sakhalin Island. Vladimir Ya. Levanidov's Biennial Memorial Meetings 5: 346-359 [in Russian].

Meister F. (1912) Die Kieselalgen der Schweiz. Beiträge zur Kryptogamenflora der Schweiz. Vol. 4, Issue 1: 1-254, 48 plates. Bern, K.J. Wyss.

Moore J.W. (1972) Composition and structure of algal communities in a tributary stream of Lake Ontario. Canadian Journal of Botany 50: 1663-1674. http://dx.doi.org/10.1139/b72-205

Moore J.W. (1981) Seasonal cycles of rare species of epipelic diatoms in a hardwater temperate-zone stream. Nova Hedwigia 34: $247-258$.

Morales E.A., Fernández E., Kociolek J.P. (2009) Epilithic diatoms (Bacillariophyta) from cloud forest and alpine streams in Bolivia, South America 3: diatoms from Sehuencas, Carrasco National Park, Department of Cochabamba. Acta Botanica Croatica 68: 263-283.

Morosov P.A. (1929) Spisok vodorostei r. Somari. Visnik Dnipropetrovskoi Hidrobilogichnoi Stantsii 1: 67-68.

Müller O. (1909) Bacillariaceen aus Süd-Patagonien. (Engler's) Botanische Jahrbücher für Systematik, Pflanzengeschichte, und Pflanzengeographie, Leipzig 43(4), Beiblatt zu den Botanischen Jahrbüchern 100: 1-40, 2 plates.

Müller O. (1910) Bacillariaceen aus dem Nyassalande und einigen benachbarten Gebieten. (Engler's) Botanische Jahrbücher für Systematik, Pflanzengeschichte, und Pflanzengeographie, Leipzig 45: 69-122, 2 plates.
Müllner A.N. (1995) The algal species of a gravel stream "Oberer Seebach", Lunz. Jahresbericht der Biologischen Station Lunz 16: 41-49.

Nikulina T.B. (2001) The modern state of phycoflora in the Rakovskoe reservoir (Primorye Territory). V. Y. Levanidov's Biennial Memorial Meetings 1: 76-86.

Nikulina T.B. (2003) Diatom communities of Razdolnaya River (Primorye Territory). Vladimir Ya. Levanidov's Biennial Memorial Meetings 2: 254-262 [in Russian].

Nikulina T.B. (2005) Diatom algae (Bacillariophyta) from the south part of Sakhalin Island. In: Storozhenko S. Yu. (ed.) Flora and fauna of Sakhalin Island (Materials of International Sakhalin Island Project) 2: 8-20. Vladivostok, Dalnauka [in Russian].

Nikulina T.V. (2006) Algal flora of Moneron Island. In: Bogatov V.V., Barkalov V.Yu., Lelei A.S., Makarchenko E.A., Storozhenko S.Yu. (eds) Flora and fauna of Moneron Island (Materials of International Sakhalin Island Project): 21-44. Vladivostok, Dalnauka [in Russian].

Nikulina T.V. (2008) Biodiversity of diatom algae of Onon River and its tributaries (the Amur River basin): 89-98. Vladivostok, Freshwater ecosystems of the Amur River Basin [in Russian].

Nikulina T.V. (2010a) Biodiversity of algae of hot springs from Kuril Islands (Russia). Algologia 20: 334-356 [in Russian].

Nikulina T.V. (2010b) Biodiversity of algae of hot springs from the Kuril Islands (Russia). International Journal on Algae 12: 299-320.

Nikulina T.V. (2011) Spatial dynamics of periphyton algal communities and change of water quality in the Tym River basin (Sakhalin Island, Russia). Vladimir Ya. Levanidov's Biennial Memorial Meetings 5: 396-411 [in Russian].

Nikulina T. V. (2014) Species composition of algal flora of Amur River low part in 2005-2014 and water quality evaluation by biological analysis data. Vladimir Ya. Levanidov's Biennial Memorial Meetings 6: 483-500 [in Russian].

Nikulina T.V., Kociolek J.P. (2011) Diatoms from hot springs from Kuril and Sakhalin Islands (Far East, Russia). In: Seckbach J., Kociolek J.P. (eds) The Diatom World, Cellular Origin, Life in Extreme Habitats and Astrobiology 19: 333-363. Springer Science+Business Media B.V. http://dx.doi.org/10.1007/97894-007-1327-7_15

Novais M.H., Morais M.M., Rosado J., Dias L.S., Hoffmann L., Ector L. (2014) Diatoms of temporary and permanent watercourses in southern Europe (Portugal). River Research and Applications 30. http://dx.doi.org/10.1002/rra.2818

Novoveska L. (2005) Benthic algal community structure and bioaccumulation of mercury in a coastal watershed. Master of Science Thesis. Paper 924. Eastern Illinois University, Charleston, Illinois, USA.

Oppenheim D.R. (1994) Taxonomic studies of Achnanthes (Bacillariophyta) in freshwater maritime Antarctic lakes. Canadian Journal of Botany 72: 1735-1748.

Østrup E. (1918) Fresh-water diatoms from Iceland. Part I. In: Rosenvinge L.K., Warming E. (eds) The Botany of Iceland, vol. II, part I, 2: 1-98, 5 plates, Copenhagen.

Otte A.M., Bellis V.J. (1985) Edaphic diatoms of a low salinity estuarine marsh system in North Carolina - A comparative floristic study. The Journal of the Elisha Mitchell Scientific Society 101: 116-124.

Pastor R. (1991) La colección de diatomeas del Instituto Tecnológico GeoMinero de España. Boletín Geológico y Minero 102: 19-92. 
Patrick R., Reimer C.W. (1966) The diatoms of the United States. Volume 1: Fragilariaceae, Eunotiaceae, Achnanthaceae, Naviculaceae. Monographs of the Academy of Natural Sciences of Philadelphia, vol. 13: pp 1-688, 64 plates, Philadelphia.

Peerapornpisal Y., Pekthong T., Waiyaka P., Promkutkaew S. (2000) Diversity of phytoplankton and benthic algae in Mae Sa stream, Doi Suthep-Pui National Park, Chiang Mai. Natural History Bulletin of the Siam Society 48: 193-211.

Pierre J.-F. (2001) Catalogue des algues du Nord-est de la France et des régions attenantes (1959-2001). Bulletin de l'Académie Lorraine des Sciences 40: 1-100.

Poor C.J., McDonnell J.J. (2007) The effects of land use on stream nitrate dynamics. Journal of Hydrology 332: 54-68. http:// dx.doi.org/10.1016/j.jhydrol.2006.06.022

Potapova M. (2011) Planothidium haynaldii. In: Diatoms of the United States [online]. Available from http://westerndiatoms. colorado.edu/taxa/species/planothidium_haynaldii [accessed 22 Apr. 2014].

Reavie E.D., Smol J.P. (1998) Freshwater diatoms from the St. Lawrence River. Bibliotheca Diatomologica 41: 1-137.

Reiter S., Burchardt L. (2005) Relations between phosphorus, nitrogen concentration and phytoplankton structure and abundance in two ponds in the Dębina forest in Poznań. Badania fizjograficzne nad Polską Zachodnią: Botanika. Seria B, 54: 143-176.

Rich F. (1925) The algae of Leicestershire. Journal of Botany 63: 325-330.

Rivera P., Cruces F. (2009) Transfer of Achnanthes looseri Frenguelli to the genus Planothidium. Gayana Botanica 66: 95-98. http://dx.doi.org/10.4067/S0717-66432009000100010

Robinson M. (1982) Diatom analysis of Early Flandrian lagoon sediments from East Lothian, Scotland. Journal of Biogeography 9: 207-221. http://dx.doi.org/10.2307/2844664

Rochera C., Fernández-Valiente E., Van de Vijver B., Rico E., Toro M., Vincent W.F., Quesada A., Camacho A. (2013) Community structure and photosynthetic activity of benthic biofilms from a waterfall in the maritime Antarctica. Polar Biology 36: 17091722. http://dx.doi.org/10.1007/s00300-013-1388-3

Ross R., Cox E.J., Karayeva N.I., Mann D.G., Paddock T.B.B., Simonsen R., Sims P.A. (1979) An amended terminology for the siliceous components of the diatom cell. Nova Hedwigia Beiheft 64: 511-533.

Round F.E., Crawford R.M., Mann D.G. (1990) The diatoms: biology and morphology of the genera. Cambridge, Cambridge University Press.

Savateev I.N., Medvedeva L.A. (2005) Preliminary information about diatom algae of some rivers in "Bastak" nature reserve. Vladimir Ya. Levanidov's Biennial Memorial Meetings 3: 237245.

Schaarschmidt G. (1881) Specimen phycologiae aquatoriensis. Magyar Növénytani Lapok 5: 17-24.

Schmidt R., Mäusbacher R., Müller J. (1990) Holocene diatom flora and stratigraphy from sediment cores of two Antarctic lakes (King George Island). Journal of Paleolimnology 3: 55-74. http://dx.doi.org/10.1007/BF00209300

Schowe K.A. (2012) Diatom communities across a gradient of acid mine drainage on the West Coast, South Island, New Zealand. Master Thesis, School of Biological Sciences, University of Canterbury, Christchurch, New Zealand.

Schowe K.A., Harding J.S. (2014) Development of two diatombased indices: a biotic and a multimetric index for assessing mine impacts in New Zealand streams. New Zealand Journal of
Marine and Freshwater Research 48: 163-176. http://dx.doi.org $710.1080 / 00288330.2013 .852113$

Shevchenko T.F. (2007) Species composition of periphyton algae of the reservoirs of the Dnieper Cascade. Hydrobiological Journal 43: 3-42. http://dx.doi.org/10.1615/HydrobJ.v43.i5.10

Shiono M., Jordan R.W. (1995) Recent diatoms of Lake Hibara, Fukushima Prefecture. Diatom 11: 31-63. http://dx.doi. org/10.11464/diatom1985.11.0_31

Soltanpour-Gargari A., Lodenius M., Hinz F. (2011) Epilithic diatoms (Bacillariophyceae) from streams in Ramsar, Iran. Acta Botanica Croatica 70: 167-190. http://dx.doi.org/10.2478/ v10184-010-0006-5

Spaulding S.A., Lubinski D.J., Potapova M. (2010) Diatoms of the United States [online]. Available from http://westerndiatoms. colorado.edu [accessed 23 Jul. 2014].

Steinecke E. (1916) Die Algen des Zehlaubruches. Schriften der Physikalisch-Ökonomischen Gesellschaft zu Königsberg 56: $1-138$.

Stoermer E.F., Kreis R.G. Jr., Andresen N.A. (1999) Checklist of diatoms from the Laurentian Great Lakes. II. Journal of Great Lakes Research 25: 515-566. http://dx.doi.org/10.1016/S03801330(99)70759-8

Straub F. (1985) Variabilité comparée d'Achnanthes lanceolata (Bréb.) Grun. et d'Achnanthes rostrata (Bacillariophyceae) dans huit populations naturelles du Jura suisse I: approche morphologique. Bulletin de la Société Neuchâteloise des Sciences Naturelles 108: 135-150.

Szemes G. (1931) A kádártai források Diatomáceái. Die Diatomaceen der Quellen von Kádárta. Magyar Biológiai Kutató Intézet munkái Tihany 4: 320-341.

Szemes G. (1960) Aufzählung der Kryptogamen aus der Donau in Ungarn. Annales Universitatis Scientiarum Budapestinensis de Rolando Eötvös Nominatae Sectio Biologica 3: 377-400.

Temniskova-Topalova D., Ognjanova-Rumenova N. (1997) Description, comparison and biostratigraphy of the nonmarine Neogene diatom floras from Southern Bulgaria. Geologica Balcanica 27: 57-81.

Tempère J., Peragallo H. (1915) Diatomées du Monde Entier. Edition 2. Tables: 1-68. Tempère J., Arcachon, Gironde.

Terry W.A. (1908) Additional lists of Connecticut diatoms. Rhodora 10 (118): 179-184.

Topachevsky O.V., Oksiyuk O.P. (1960) Diatomovi vodorosti Bacillariophyta (Diatomeae). In: Vyznachnyk prisnovodnykh vodorostej Ukrainskoy RSR 11: 1-412. Kiev, Izdatelstvo Akademia Nauk Ukrainskoy S.S.R. [in Russian].

Tsarenko P.M., Wasser S.P., Nevo E. (eds) (2009) Algae of Ukraine: Diversity, Nomenclature, Taxonomy, Ecology and Geography Vol. 2. Bacillariophyta. Ruggell/Liechtenstein, A. R. G. Gantner Verlag.

Turskaya S.A. (2011) Bacillariophyta of microphytobenthos from some basins of the Vilejsko-Minskaya water system (Belarus). Algologia 21: 241-256.

Unrein F. (2000) Estructura y dinámica del fitoplancton estival de un lago antártico (Península Potter, Shetland del Sur). Ecología Austral 10: 169-179.

Unrein F., Vinocur A. (1999) Phytoplankton structure and dynamics in a turbid Antarctic lake (Potter Peninsula, King George Island). Polar Biology 22: 93-101. http://dx.doi.org/10.1007/ s003000050395

Unrein F., Izaguirre I., Massana R., Balagué V., Gasol J.M. (2005) Nanoplankton assemblages in maritime Antarctic lakes: characterisation and molecular fingerprinting comparison. Aquatic 
Microbial Ecology 40: 269-282. http://dx.doi.org/10.3354/ ame040269

van Dam H., Mertens A., Sinkeldam J. (1994) A coded checklist and ecological indicator values of freshwater diatoms from The Netherlands. Netherlands Journal of Aquatic Ecology 28: 117133. http://dx.doi.org/10.1007/BF02334251

van der Werff A. (1955) A new method of concentrating and cleaning diatoms and other organisms. Verhandlungen Internationalen Vereinigung für Theoretische und Angewandte Limnologie 2: 276-277.

Van de Vijver B., Frenot Y., Beyens L. (2002) Freshwater diatoms from Ile de la Possession (Crozet Archipelago, Subantarctica). Bibliotheca Diatomologica 46: 1-412.

Van de Vijver B., Sterken M., Vyverman W., Mataloni G., Nedbalová L., Kopalová K., Elster J., Verleyen E., Sabbe K. (2010) Four new non-marine diatom taxa from the Subantarctic and Antarctic Regions. Diatom Research 25: 431-443. http://dx.doi. org/10.1080/0269249X.2010.9705861

Van de Vijver B., Wetzel C., Kopalová K., Zidarova R., Ector L. (2013) Analysis of the type material of Achnanthidium lanceolatum Brébisson ex Kützing (Bacillariophyta) with the description of two new Planothidium species from the Antarctic Region. Fottea 13: 105-117.

Vinocur A., Pizarro H. (2000) Microbial mats of twenty-six lakes from Potter Peninsula, King George Island, Antarctica. Polar Biology 22: 93-101. http://dx.doi.org/10.1023/A:102651 $\overline{1125146}$
Vinocur A., Unrein F. (2000) Typology of lentic water bodies at Potter Peninsula (King George Island, Antarctica) based on physical-chemical characteristics and phytoplankton communities. Polar Biology 23: 858-870. http://dx.doi.org/10.1007/ s003000000165

Wendker S. (1990) Untersuchungen zur subfossilen und rezenten Diatomeenflora des Schlei-Ästuars (Ostsee). Bibliotheca Diatomologica 20: 1-268.

Wetzel C.E., Ector L. (2014) Taxonomy, distribution and autecology of Planothidium bagualensis sp. nov. (Bacillariophyta) a common monoraphid species from southern Brazilian rivers. Phytotaxa 156: 201-210. http://dx.doi.org/10.11646/phytotaxa.156.4.2

Wetzel C.E., Van de Vijver B., Hoffmann L., Ector L. (2013) Planothidium incuriatum sp. nov. a widely distributed diatom species (Bacillariophyta) and type analysis of Planothidium biporomum. Phytotaxa 138: 43-57. http://dx.doi.org/10.11646/phytotaxa.138.1.6

Woodhead N., Tweed R.D. (1958) A check list of tropical West African algae (fresh- and brackish- water). Hydrobiologia 11: 299-395. http://dx.doi.org/10.1007/BF0001 $\overline{8696}$

Manuscript received 12 Aug. 2014; accepted in revised version 3 Sep. 2014.

Communicating Editor: Elmar Robbrecht. 